\title{
Forage Production and Selection for Vigor in Meadow and Hybrid Bromegrass in the Northern Great Plains
}

\author{
R. Martine Similien1, Arvid Boe ${ }^{1}{ }^{*}$, Bruce Coulman ${ }^{2}$ \\ ${ }^{1}$ Plant Sciences Department, South Dakota State University, Brookings, SD, USA \\ ${ }^{2}$ Plant Science Department, University of Saskatchewan, Saskatoon, Canada \\ Email: rmsimilien@gmail.com, *arvid.boe@sdstate.edu, bruce.coulman@usask.ca
}

How to cite this paper: Similien, R.M., Boe, A. and Coulman, B. (2020) Forage Production and Selection for Vigor in Meadow and Hybrid Bromegrass in the Northern Great Plains. American Journal of Plant Sciences, 11, 91-110. https://doi.org/10.4236/ajps.2020.111008

Received: October 28, 2019

Accepted: January 14, 2020

Published: January 17, 2020

Copyright ( 2020 by author(s) and Scientific Research Publishing Inc. This work is licensed under the Creative Commons Attribution International License (CC BY 4.0).

http://creativecommons.org/licenses/by/4.0/

(c) (i) Open Access

\begin{abstract}
Meadow bromegrass (Bromus riparius Rehmann) is an important forage crop in Canada and the Intermountain West, but it has not been extensively evaluated in the northern Great Plains (NGP). Our objectives were to 1) evaluate meadow, smooth, and hybrid bromegrasses for forage production under intensive management in eastern South Dakota, and 2) evaluate the effect of selection for vigor in multiple environments on forage production of meadow bromegrass. Thirteen populations ( 7 meadow bromegrass, 5 hybrid bromegrass, and 1 smooth bromegrass) were evaluated for 4 yrs (2005-2007, 2009) at Brookings, SD. Biomass at anthesis was greater for smooth $\left(6.75 \mathrm{Mg} \mathrm{ha}^{-1}\right)$ than for meadow or hybrid brome $\left(5.4 \mathrm{Mg} \mathrm{ha}^{-1}\right)$ in 2005 , but production at anthesis during 2006 and 2007 was similar for meadow and smooth bromegrass. Regrowth harvested during July and October 2005 and November 2006 was greater for meadow than smooth or hybrid bromegrass. Forage production at anthesis in 2009, after rest (i.e., no cutting) and fertilization in 2008, was $4.2 \mathrm{Mg} \mathrm{ha}^{-1}$ for meadow bromegrass compared with $3.3 \mathrm{Mg} \mathrm{ha}^{-1}$ and $2.6 \mathrm{Mg}$ $\mathrm{ha}^{-1}$ for hybrid and smooth bromegrass, respectively. Smooth and hybrid bromegrasses had more leaves.tiller ${ }^{-1}$ than meadow bromegrass. After 6 yrs, meadow bromegrass had higher tiller density and greater potential for tolerating multiple harvests during a growing season than did smooth or hybrid bromegrass. Selection for vigor in multiple environments in North America resulted in experimental populations of meadow bromegrass with superior forage yield compared with 'Fleet' on marginal crop land in the northern Great Plains.
\end{abstract}

\section{Keywords}

Bromus riparius, Smooth Bromegrass, Bromus inermis, Morphology, Phytomer, Biomass Partitioning, Leaf Ratio, Tiller Density, Marginal Cropland 


\section{Introduction}

Meadow bromegrass (Bromus riparius Rehmann) is a bunch type of bromegrass with good regrowth ability [1]. Its leafy production and rapid growth make it desirable for pastures in the central parkland region of Canada [1] [2] [3]. Due to shorter rhizomes, meadow bromegrass is less aggressive than smooth bromegrass (Bromus inermis Leyss) in perennial grass-legume mixtures [4]. Meadow bromegrass is relatively winter-hardy and has shown potential for late summer and fall regrowth [2] [5].

Smooth bromegrass and meadow bromegrass may be successfully crossed to produce hybrid bromegrass [2] [6] [7]. The interspecific hybrid expresses characteristics of both parents and has shown potential for hay during spring and for pasture during the summer and autumn [2] [6].

Pasture and forage lands of the eastern Great Plains states have been greatly improved by the widespread use and cultivation of smooth bromegrass [8]. However, in the northern Great Plains there is still a need for perennial grasses that furnish high-quality forage for beef cattle (Bos taurus L.) throughout the growing season [9]. Breeding of cross-pollinating, perennial forage grasses is generally focused on the development of superior synthetic cultivars and improved heterogeneous populations [1]. Although few species will be better adapted to a region than those already commonly grown, continued screening is needed to identify the potential of species in previously untested environments [10].

Harvest management studies on smooth bromegrass in rainfed environments [11] indicated that long-term yields in pure stands are maximized by taking the initial harvest after heading and having infrequent regrowth harvests. In a grazing system, Harrison and Romo [12] recommended a single defoliation per year and found no increase in annual production from regrowth taken after initial harvest at later vegetative stages during dry years. They also concluded that regrowth was not related to stage of growth of initial harvest, but rather was dependent on growing conditions.

Jensen et al. [13] examined the regrowth capacity of meadow bromegrass under irrigation in Utah with an application of about $2.5 \mathrm{~cm}$ of water. $\mathrm{week}^{-1}$ from April through September, and harvests taken about every 30 days. Regrowth yield was ca. $1.3 \mathrm{Mg} \mathrm{ha}^{-1}$ per harvest for 28 parental clones and $2.4 \mathrm{Mg} \mathrm{ha}^{-1}$ for their half-sib progenies. The lowest yields were obtained during July and August.

Less is known about the effects of harvest management on meadow bromegrass compared to smooth bromegrass in semiarid environments, especially the northern Great Plains. However, Knowles et al. [14] reported meadow and hybrid bromegrass produced more regrowth than smooth bromegrass in multiple-cut systems in Canada.

Therefore, objectives of this study were to: 1) compare forage yield and persistence of smooth, meadow, and hybrid bromegrasses under intensive simulated hay production, 2) determine if differences among meadow and smooth 
bromegrass and their hybrid for persistence and biomass production were associated with variation in morphological characteristics, and 3) compare recently selected experimental populations of meadow bromegrass from a wide geographic area in North America for forage production and persistence on marginal cropland in the northern Great Plains.

\section{Materials and Methods}

\section{Forage Production}

Field plots were located at Brookings, SD $\left(44^{\circ} 18^{\prime} 23^{\prime \prime} \mathrm{N} 96^{\circ} 47^{\prime} 17^{\prime \prime} \mathrm{W}\right)$. The soil was a Hamerly-Badger complex silt loam (fine-loamy, mixed, frigid aeric calciaquolls-fine, smectitic, frigid vertic argiaquolls). The soil at the site was poorly drained with high lime content. Seed of 13 populations ['Signal' smooth bromegrass (S), 'Fleet' and 'Paddock' meadow bromegrasses (M), 'AC Success' and 'AC Knowles' hybrid bromegrass (H), five experimental meadow bromegrass populations, and three experimental hybrid bromegrass populations (Table 1)] of Bromus were provided by Dr. Bruce Coulman, University of Saskatchewan, Saskatoon]. Signal was chosen to represent smooth bromegrass because it was one of the parents for the hybrids and has demonstrated high forage and seed production characteristics over a wide area in the northern Great Plains [4]. Seed was planted in the greenhouse in $2.5-\mathrm{cm}$ diameter $\times 16-\mathrm{cm}$ depth cone-tainers (Steuwe \& Sons Inc., Tangent, OR 97389) in March 2004; seedlings were transplanted to the field in June 2004. The experiment was a randomized complete block design with four replicates of single-row plots. Each plot contained 10 plants spaced equidistant within a 3-m long row; distances between rows and in alleys separating ranges were $0.9 \mathrm{~m}$. No harvests were taken during the transplant year. Data were collected during 2005, 2006, 2007, and 2009.

In early May 2008, stands were evaluated and determined to be nutrient deficient and declining. Therefore, the experimental area was uniformly fertilized with a mixed granular fertilizer surface applied at rates of $112 \mathrm{~kg} \mathrm{~N} \mathrm{ha}^{-1}, 3.5 \mathrm{~kg}$ $\mathrm{P}_{2} \mathrm{O}_{5} \mathrm{ha}^{-1}$, and $13.5 \mathrm{~kg} \mathrm{~K}_{2} \mathrm{O} \mathrm{ha}{ }^{-1}$. Stands were allowed to grow until seed maturity to encourage root and rhizome/crown development to invigorate the stands, at which time the forage was harvested with a sickle bar mower and removed. No forage production data were taken. Forage yield determinations resumed on 18 June 2009.

The first harvests during 2005 (20 June), 2006 (27 June), and the only harvests during 2007 (24 June) and 2009 (18 June) were when most of the entries were in early to late anthesis. The initial harvests each year were done by hand with a rice knife. Stubble height was about $8 \mathrm{~cm}$.

The first regrowth harvest during 2005 was on 28 July when all of the entries were in the vegetative/elongating stage; the second regrowth harvest during 2005 was on 28 October when all of the entries were in the vegetative stage. The first regrowth harvest during 2006 was on 26 November when all entries were dormant and in the vegetative/elongating stage. All of the regrowth harvests were done with a rotary mower equipped with a bagger. Stubble height was ca. $5 \mathrm{~cm}$. 
Table 1. Bromegrass (Bromus spp.) entries in a forage production and morphology evaluation trial established at Brookings, SD† during June 2004.

\begin{tabular}{ccc}
\hline Entry $\dagger$ & Population Type & Species \\
\hline Signal S & Cultivar & B. inermis \\
AC Knowles H & Cultivar & B. inermis $\times$ B. riparius \\
AC Success H & Cultivar & B. inermis $\times$ B. riparius \\
Fleet M & Cultivar & B. riparius \\
Paddock M & Cultivar & B. riparius \\
S9043 M & Experimental & B. riparius \\
S9452 M & Experimental & B. riparius \\
S9454 M & Experimental & B. riparius \\
S9455 M & Experimental & B. riparius \\
S9457 M & Experimental & B. riparius \\
S9073 H & Experimental & B. inermis $\times$ B. riparius \\
S9183 H & Experimental & B. inermis $\times$ B. riparius \\
S9478 H & Experimental & B. inermis $\times$ B. riparius \\
\hline
\end{tabular}

$\dagger \mathrm{H}=$ hybrid bromegrass, $\mathrm{M}=$ meadow bromegrass, and $\mathrm{S}=$ smooth bromegrass.

For all harvests, plot fresh weights were taken in the field. Sub-samples were dried at $60^{\circ} \mathrm{C}$ for 72 hours to determine moisture concentration for calculation of dry matter yield. Dry matter yields were determined for each harvest. Yield data were subjected to analyses of variance for individual years and harvests. Populations were considered fixed effects.

Weather conditions at Brookings, SD for January 2005 through December 2007 and 30-yr averages are provided in Table 2

(http://www.climate.sdstate.edu, October, 2009). Temperatures were near normal throughout the experiment. Total annual precipitation was $841 \mathrm{~mm}$ for 2005, $584 \mathrm{~mm}$ for 2006, and $581 \mathrm{~mm}$ for 2007. The 30 -yr average total is 580 $\mathrm{mm}$. Precipitation during the growing season (April- September) was $667 \mathrm{~mm}$ for 2005, $489 \mathrm{~mm}$ for 2006 and $413 \mathrm{~mm}$ for 2007. The 30-yr average for growing season precipitation is $451 \mathrm{~mm}$. From April through June 2005, precipitation was $26 \%$ above normal and $65 \%$ greater than the same time period during 2006 (Table 2). Low precipitation during July $2006(6 \mathrm{~mm})$ restricted regrowth and a mid-season regrowth harvest. Therefore, the only regrowth harvest was not taken until November. For 2007, June through July precipitation was $<45 \%$ of normal, and regrowth was determined to be insufficient for harvest anytime during the duration of the growing season. Precipitation during September 2008 through June 2009 was $90 \%$ of normal (data not shown).

\section{Morphology}

For the initial harvests during 2005 and 2006, random samples of 25 reproductive tillers were collected from each entry for quantitative morphology. Tillers were dried and fractionated into individual phytomers. Number of phytomer.tiller ${ }^{-1}$ and length and weight of leaf and stem components were determined for each phytomer. The numbering system for phytomers used here designates the apical phytomer as Phytomer 1 and subtending phytomers in sequence [15]. 
Table 2. Weather data for 2005, 2006, 2007, and the 30-yr average for Brookings, SD.

\begin{tabular}{|c|c|c|c|c|c|c|c|c|c|c|c|c|}
\hline & Jan & Feb & Mar & Apr & May & June & July & Aug & Sept & Oct & Nov & Dec \\
\hline \multicolumn{13}{|c|}{$\underline{2005}$} \\
\hline Temp (C) & -11 & -4.4 & -1.1 & 8.9 & 12.3 & 20.7 & 22.4 & 20.2 & 11.9 & 9.0 & 1.1 & -9.0 \\
\hline Precip (mm) & 9 & 17 & 14 & 47 & 96 & 152 & 88 & 89 & 194 & 67 & 30.7 & 37 \\
\hline \multicolumn{13}{|c|}{$\underline{2006}$} \\
\hline Temp (C) & -3.3 & -7.8 & -0.6 & 8.9 & 14 & 19.6 & 23.0 & 20.7 & 12.9 & 6.2 & 0 & -3.9 \\
\hline Precip (mm) & 4 & 3 & 40 & 67 & 51 & 60 & 6 & 144 & 162 & 5 & 9 & 38 \\
\hline \multicolumn{13}{|c|}{$\underline{2007}$} \\
\hline Temp (C) & -8.4 & -12.2 & 1.1 & 5.0 & 16.1 & 20.0 & 22.2 & 20.0 & 16.1 & 10.6 & 0 & -10.6 \\
\hline Precip (mm) & 7.1 & 12.5 & 44 & 92 & 47 & 76 & 3.6 & 164 & 30.5 & 88.7 & 0.51 & 15 \\
\hline \multicolumn{13}{|c|}{30 -yr average } \\
\hline Temp (C) & -11.8 & -7.9 & -1.1 & 6.8 & 13.8 & 19.1 & 21.7 & 20.5 & 15.2 & 8.0 & -1.1 & -8.8 \\
\hline Precip (mm) & 8.6 & 10.2 & 33 & 52 & 75 & 107 & 79 & 75 & 63 & 45 & 25 & 7 \\
\hline
\end{tabular}

For regrowth harvests during 2005, number of leaves, and leaf and stem components by weight were determined from 25 tillers collected from each of the four plots of each population, for a total of 100 tillers.population $^{-1}$, prior to harvest. Tillers were allowed to air dry indoors prior to separation into leaf and stem fractions.

On 18 June 2009, two $0.25-\mathrm{m}^{2}$ subplots were harvested from each of the four plots of each population for determinations of tiller density, leaves tiller $^{-1}$, distribution of biomass among vegetative and reproductive tillers, and distribution of biomass among leaf and stem fractions of individual phytomers. From each subplot for each of the five cultivars (i.e., Fleet and Paddock meadow bromegrass, AC Success and AC Knowles hybrid bromegrass, and Signal smooth bromegrass), five reproductive tillers were randomly chosen for the phytomeric analysis of biomass distribution between leaf and stem components.

Leaf and stem components were weighed on a balance with milligram accuracy. Analysis of variance [16] was used to determine the importance of phytomer as a source of variation in blade, sheath, and internode lengths and weights. Fisher's least significant difference $(\mathrm{p}=0.05)$ was used to separate means.

Data Analysis for Forage Production and Morphology

Orthogonal contrasts [16] were used to answer questions posed prior to establishing the experiment regarding: 1) the potential value of meadow and hybrid bromegrasses, relative to smooth bromegrass, for forage production, 2) which of meadow or hybrid bromegrass has the greatest potential for forage production, and 3) do smooth, meadow and hybrid bromegrasses differ for morphological characteristics associated with forage production. Student's $t$-tests were used to determine significance of individual contrasts [17].

Evaluation of Selection for Vigor in Multiple Environments

In July 2011 open-pollinated seed was collected and bulked from the 15 (a 5\% 
selection intensity from a total of 280 meadow bromegrass plants) most vigorous meadow bromegrass plants (hereafter referred to as SD Select), based on visual assessment of plant height and number and size of panicles. Numbers of selected plants from which open-pollinated seed was bulked were five from S-9454, four from S-9452, three from S-9457, two from S-9043, and one from Paddock. In March 2012, seeds of SD Select and seven other entries (four meadow bromegrasses and three hybrid bromegrasses) were planted in $2.5-\mathrm{cm}$ diameter $\mathrm{x}$ $16-\mathrm{cm}$ depth cone-tainers (Steuwe \& Sons, Tangent, OR 97389) in the greenhouse. Seedlings were transplanted to the field at Brookings in June 2012. The soil was a Badger-McIntosh complex (fine, smectitic, frigid vertic Argiaquolls-fine, silty, mixed superactive, frigid aquic Calciudolls). The experimental area was poorly drained, slightly saline tilled crop land. It was generally too wet in the spring for timely planting of conventional grain crops, and had not been planted to a crop for two consecutive years. Volunteer vegetation was mowed several times during the 2011 growing season and in the spring 2012 to control weeds. The most common weedy plants on the site were foxtail barley (Hordeum jubatum L.) and white prairie aster [(Symphytotrichum falcatum (Lindl.) G.L. Nesom]. Both species are highly adapted to and indicators of saline soils in the northern Great Plains. The area was mowed to a stubble height of about 2 $\mathrm{cm}$ just prior to transplanting. The trial contained five replications of $2.5-\mathrm{m}$ long single-row plots containing 8 equidistant plants for each of the nine entries. Inter-plot spacing was $0.61 \mathrm{~m}$ (Figure 1 ).

In addition to SD Select, other entries were 'Fleet' meadow bromegrass [18], 'AC Knowles' hybrid bromegrass [7], S-9522, a 15-clone synthetic cultivar of meadow bromegrass selected at Saskatoon, Saskatchewan for vigor, regrowth, and disease resistance, S-9553, a 37-clone synthetic cultivar of meadow bromegrass selected at Sainte-Foy, Quebec for vigor, regrowth, and disease resistance, S-9554, a 10-clone synthetic cultivar of meadow bromegrass selected at Charlottetown, PEI for vigor, regrowth, and disease resistance, S-9555, a 10-clone synthetic cultivar of hybrid bromegrass selected at Charlottetown, PEI for vigor, regrowth, and disease resistance, and S-9478F, a 10-clone synthetic cultivar of hybrid bromegrass selected at Saskatoon for forage yield. All of the S-entries of meadow bromegrass were selected out of the same 13 entries in the 2004 nursery, including 'Fleet', 'Paddock', and six experimental lines of meadow bromegrass, that SD Select was selected from, at their respective locations.

Plots were harvested for forage yield on 7 August 2013, 17 July 2014, 3 August and 9 October 2015, 1 September 2016, and 20 July 2017. Each of these populations headed during mid to late May. Stage of development at harvest was mature seed, with the exception of the regrowth harvest on 9 October 2015, which was vegetative. Harvest was by hand with a rice knife. Stubble height was about 5 $\mathrm{cm}$. Forage from each row was weighed separately in the field and grab samples were dried at $60^{\circ} \mathrm{C}$ for 72 hours to reach constant weight for dry matter forage yield determinations. Plant counts were taken for each row on 17 July 2014. 


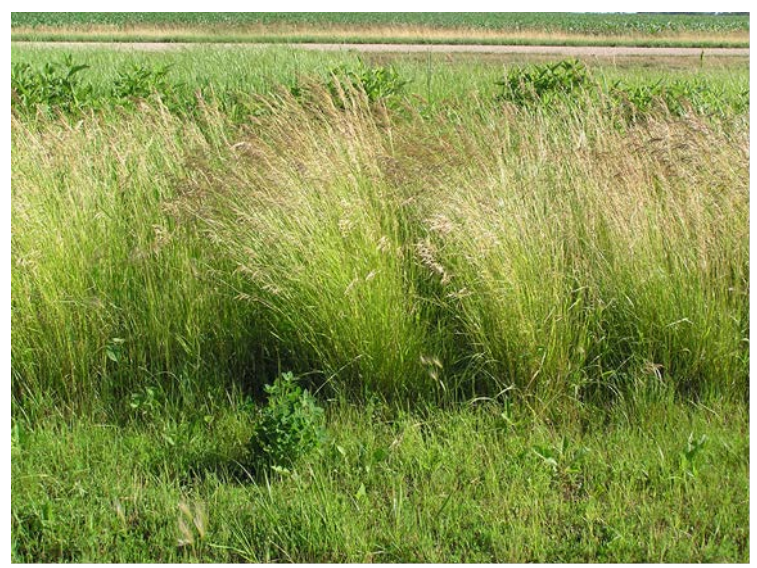

Figure 1. Rows of five-year-old plants of meadow bromegrass on marginal crop land at Brookings, SD on 20 July 2017.

Because of low plant counts ( $<30 \%$ stand) in spring 2015, harvesting was discontinued for plots of S-9478F, S-9555, and 'AC Knowles'. For data analysis, the two harvests in 2015 were pooled. No fertilizer was applied during 2013 through 2014. Beginning in 2015, $112 \mathrm{~kg} \cdot \mathrm{ha}^{-1} \mathrm{~N}$ in the form of urea was applied each year in late April. A 2-factor analysis of variance with population and year fixed effects was conducted to determine if differences occurred among populations and among years for forage production.

\section{Results}

\section{Forage Production}

Differences were found among the 13 populations for forage production for all seven of the harvests taken during 2005 through 2009 (Table 3). During 2005, Signal smooth bromegrass produced $20 \%$ more forage than the average of the meadow and hybrid populations for the initial growth and 35\% more forage from the first regrowth cycle. No difference was found between the means of the meadow and hybrid populations for the initial harvest. However, mean forage production of the 5 hybrids was $16 \%$ greater than that of the 7 meadow populations for the first regrowth cycle. For the second regrowth harvested during October, the average of the meadow and hybrid populations exceeded the mean of smooth bromegrass by $61 \%$; and the meadow populations out-produced the hybrids by $37 \%$. Regrowth from two harvests, averaged across all of the 13 populations, exceeded $3 \mathrm{Mg} \mathrm{ha}^{-1}$, which was $36 \%$ of the total production for the year (Table 3).

For the initial and regrowth harvests in 2006, the average yield of the meadow and hybrid populations was similar to the mean yield for Signal smooth bromegrass. However, the meadow populations produced $22 \%$ and $54 \%$ more forage than the hybrid populations for initial and regrowth harvests, respectively. Regrowth yield from a single harvest at the end of the growing season, averaged across populations, was $0.5 \mathrm{Mg} \mathrm{ha}^{-1}$, which was $<15 \%$ of the total production for the year (Table 3). 
Table 3. Mean dry matter forage production of populations of meadow bromegrass (M), smooth bromegrass $(\mathrm{S})$, and meadow $\times$ smooth bromegrass hybrids $(\mathrm{H})$ over a five-yr period at Brookings, $\mathrm{SD} \dagger$.

\begin{tabular}{|c|c|c|c|c|c|c|c|}
\hline \multirow[b]{2}{*}{ Entry $\ddagger$} & \multicolumn{3}{|c|}{2005} & \multicolumn{2}{|c|}{2006} & \multirow{2}{*}{$\begin{array}{c}2007 \\
24 \text { June }\end{array}$} & \multirow{2}{*}{$\begin{array}{c}2009 \\
18 \text { June }\end{array}$} \\
\hline & 20 June & 28 July & 28 Oct. & 27 June & 26 Nov. & & \\
\hline & \multicolumn{7}{|c|}{$\mathrm{Mg} \mathrm{ha}^{-1}$} \\
\hline S9454 M & 5.46 & 1.87 & 1.50 & 3.72 & 0.89 & 2.40 & 5.07 \\
\hline S9183 H & 4.80 & 2.10 & 0.77 & 2.69 & 0.43 & 1.65 & 2.73 \\
\hline S9073 H & 5.10 & 2.09 & 1.33 & 2.85 & 0.42 & 1.62 & 3.27 \\
\hline Paddock M & 5.32 & 1.95 & 1.42 & 3.87 & 0.53 & 2.05 & 4.22 \\
\hline S9455 M & 5.27 & 1.85 & 1.22 & 3.50 & 0.71 & 2.35 & 2.98 \\
\hline Fleet M & 5.37 & 1.65 & 1.45 & 3.26 & 0.64 & 2.19 & 3.97 \\
\hline Success H & 5.50 & 1.95 & 0.77 & 2.67 & 0.22 & 1.68 & 3.36 \\
\hline Knowles H & 5.64 & 1.94 & 1.20 & 3.01 & 0.48 & 1.21 & 2.81 \\
\hline S9457 M & 5.21 & 1.70 & 1.36 & 2.98 & 0.60 & 1.93 & 3.90 \\
\hline S9043 M & 5.75 & 1.64 & 1.63 & 3.81 & 0.56 & 2.06 & 4.73 \\
\hline S9478 H & 5.57 & 2.17 & 1.03 & 3.43 & 0.52 & 1.90 & 4.27 \\
\hline S9452 M & 5.57 & 1.77 & 1.23 & 3.82 & 0.47 & 1.71 & 4.86 \\
\hline Signal S & 6.75 & 2.56 & 0.77 & 3.00 & 0.25 & 2.18 & 2.06 \\
\hline \multicolumn{8}{|c|}{ Contrast } \\
\hline$M+H$ vs. $S$ & $* *$ & $* *$ & $* *$ & NS & NS & NS & $* *$ \\
\hline M vs. $\mathrm{H}$ & NS & $* *$ & $* *$ & $* *$ & $\dagger$ & $* *$ & $* *$ \\
\hline
\end{tabular}

$\mathrm{NS}, \dagger,{ }^{*}$ Contrast not significant or significant at the 0.10 or 0.01 level, respectively. $\ddagger \mathrm{H}=$ hybrid, $\mathrm{M}=$ meadow, and $\mathrm{S}=$ smooth bromegrass.

For the only harvest of the third production year (i.e., 2007), the average of the meadow and hybrid populations was similar to the mean for smooth bromegrass. However, the mean of the meadow populations was $30 \%$ greater than the mean of the hybrid populations. Five out of the seven meadow populations produced $>2.0 \mathrm{Mg} \mathrm{DM} \mathrm{ha}{ }^{-1}$, whereas, none of the five hybrid populations reached that yield level (Table 3 ).

The average forage production of the meadow and hybrid populations was $87 \%$ greater than the mean for smooth bromegrass in 2009; and the meadow bromegrass populations produced $29 \%$ more forage than the hybrid bromegrass populations (Table 3).

Morphology

Reproductive tillers of hybrid bromegrass produced more leaves.tiller ${ }^{-1}$ than those of meadow bromegrass (data not shown). However, the general pattern of biomass distribution among phytomers was similar for the two types. For tillers of meadow bromegrass, which produced about four aerial phytomers, the internode from the most distal leaf bearing phytomer (i.e., Phytomer 2) was the heaviest. Similarly, although tillers of hybrid bromegrass had about one more aerial 
phytomer than those of meadow bromegrass, the heaviest internodes were located in the two distal leaf-bearing phytomers (i.e., Phytomers 2 and 3) (Table 4 and Table 5).

The smaller size of leaves and internodes during 2006 compared with 2005 was presumably due to the difference in spring precipitation between the two years (Table 2). Sheath weight and blade weight were also influenced by phytomer position. The heaviest blades and sheaths were generally found in Phytomers 2 and 3, which was similar to what has been reported for smooth bromegrass [19] (Table 4 and Table 5).

Differences in number of leaves.tiller ${ }^{-1}$ were observed among populations for first regrowth during July 2005. Smooth bromegrass had more leaves.tiller ${ }^{-1}$ than the average leaves.tiller ${ }^{-1}$ of the meadow and hybrid bromegrass populations; and, hybrid populations had more leaves.tiller ${ }^{-1}$ than the meadow bromegrass populations. Signal smooth bromegrass possessed more leaves.tiller ${ }^{-1}$ than the average of the hybrid and meadow bromegrass populations from the second regrowth in October 2005. The mean number of leaves.tiller ${ }^{-1}$ for the hybrid and meadow populations were similar (Table 6).

Table 4. Biomass partitioning among phytomers of reproductive tillers of initial growth harvested near anthesis during 2005 and 2006 for meadow bromegrass, averaged across seven populations, at Brookings, $\mathrm{SD}$.

\begin{tabular}{ccccccc}
\hline & \multicolumn{2}{c}{ Internode weight } & \multicolumn{2}{c}{ Sheath weight } & \multicolumn{2}{c}{ Blade weight } \\
\hline \multirow{2}{*}{ Phytomer } & 2005 & 2006 & 2005 & 2006 & 2005 & 2006 \\
\hline & & & \multicolumn{2}{c}{--- mg---- } & & \\
1 & $334 \mathrm{~b}$ & $199 \mathrm{~b}$ & ----- & ---- & ---- & $-\cdots-$ \\
2 & $395 \mathrm{a}$ & $274 \mathrm{a}$ & $121 \mathrm{~b}$ & $83 \mathrm{~b}$ & $69 \mathrm{~b}$ & $40 \mathrm{~b}$ \\
3 & $302 \mathrm{c}$ & $179 \mathrm{~b}$ & $132 \mathrm{a}$ & $96 \mathrm{a}$ & $81 \mathrm{a}$ & $50 \mathrm{a}$ \\
\hline
\end{tabular}

Means within columns within years followed by different letters are significantly different at the 0.05 level.

Table 5. Biomass partitioning among phytomers of reproductive tillers of initial growth harvested near anthesis during 2005 and 2006 for hybrid bromegrass, averaged across five populations, at Brookings, SD.

\begin{tabular}{ccccccc}
\hline & \multicolumn{2}{c}{ Internode weight } & \multicolumn{2}{c}{ Sheath weight } & \multicolumn{2}{c}{ Blade weight } \\
\hline \multirow{2}{*}{ Phytomer } & 2005 & 2006 & 2005 & 2006 & 2005 & 2006 \\
\hline & & & \multicolumn{2}{c}{--- -mg---- } & & \\
1 & $294 \mathrm{a}$ & $184 \mathrm{~b}$ & ---- & ---- & ---- & ---- \\
2 & $339 \mathrm{a}$ & $241 \mathrm{a}$ & $126 \mathrm{~b}$ & $61 \mathrm{~b}$ & $85 \mathrm{c}$ & $39 \mathrm{~b}$ \\
3 & $337 \mathrm{a}$ & $203 \mathrm{ab}$ & $140 \mathrm{a}$ & $78 \mathrm{a}$ & $121 \mathrm{a}$ & $65 \mathrm{a}$ \\
4 & $285 \mathrm{~b}$ & $126 \mathrm{c}$ & $118 \mathrm{~b}$ & $63 \mathrm{ab}$ & $101 \mathrm{~b}$ & $59 \mathrm{a}$ \\
\hline
\end{tabular}

Means within columns within years followed by different letters are significantly different at the 0.05 level. 
Table 6. Mean number of leaves.tiller ${ }^{-1}$ for first (28 July) and second (21 Oct.) regrowth cycles of 13 populations of bromegrass during 2005 at Brookings, SD.

\begin{tabular}{|c|c|c|}
\hline Entry† & 28 July & 21 October \\
\hline S9454 M & 4.40 & 4.17 \\
\hline S9183 H & 5.83 & 4.75 \\
\hline S9073 H & 5.85 & 4.65 \\
\hline Paddock M & 4.50 & 3.96 \\
\hline S9455 M & 4.15 & 4.19 \\
\hline Fleet M & 4.73 & 4.46 \\
\hline Success H & 6.58 & 4.21 \\
\hline Knowles H & 5.50 & 4.29 \\
\hline S9457 M & 4.38 & 4.35 \\
\hline S9043 M & 4.44 & 4.44 \\
\hline S9478 H & 6.02 & 4.21 \\
\hline S9452 M & 4.17 & 4.52 \\
\hline \multirow[t]{2}{*}{ Signal S } & 6.04 & 6.52 \\
\hline & $\underline{\text { Contrast }}$ & \\
\hline$M+H$ vs. $S$ & ** & $* *$ \\
\hline M vs. H & ** & NS \\
\hline
\end{tabular}

NS, ${ }^{* *}$ Contrast not significant or significant at the 0.01 level, respectively. $\ddagger \mathrm{H}=$ hybrid, $\mathrm{M}=$ meadow, and $\mathrm{S}=$ smooth bromegrass.

Although leaf mass-tiller ${ }^{-1}$ accounted for most of the dry matter for second regrowth during October 2005 for all of the populations, first and second regrowth tillers of Signal smooth bromegrass had smaller leaf fractions than the average of the meadow and hybrid populations. Also, the meadow populations had higher leaf fraction than the hybrids (Table 7). The ability to detect differences among populations for this trait was due to the large sample size $(n=100$ tillers).

Similar patterns were found for cultivars for all three types of bromegrass for biomass partitioning among leaf and stem components among the three uppermost leaf bearing phytomers of reproductive tillers (i.e., Phytomers 2-4) in 2005 and 2009. The general trend was an acropetal decrease in organ weights from Phytomer 4 through Phytomer 2 (data not shown). Correspondingly, the leaf-to-stem ratio of each phytomer decreased acropetally from Phytomer 4 through Phytomer 2 for all three types (Table 8). However, the leaf-to-stem ratio, averaged across phytomers, was greatest for smooth bromegrass, intermediate for hybrid bromegrass, and smallest for meadow bromegrass in 2009 (Table 9).

The gross morphologies of the six-yr-old stands of meadow bromegrass were distinctly different than those of the hybrids and smooth bromegrass. Populations of meadow bromegrass had higher tiller density, greater percent vegetative tillers by count and weight, and fewer leaves in vegetative tillers than the hybrid 
and smooth bromegrass populations. In 2009, as was found in 2005, vegetative tillers of meadow bromegrass had fewer leaves than tillers of hybrid and smooth bromegrass, but the vegetative tiller fraction of forage yield was higher for meadow than hybrid or smooth bromegrass (Table 10).

Table 7. Means for leaf fractions [leaf weight/(leaf weight + stem weight)] for first (28 July) and second (21 October) cycles of regrowth for 13 populations of bromegrass during 2005 at Brookings, SD.

\begin{tabular}{|c|c|c|}
\hline Entry $\dagger$ & 28 July & 21 October \\
\hline S9454 M & 0.85 & 0.96 \\
\hline S9183 H & 0.82 & 0.98 \\
\hline $\mathrm{S} 9073 \mathrm{H}$ & 0.73 & 0.93 \\
\hline Paddock M & 0.84 & 0.98 \\
\hline S9455 M & 0.86 & 0.98 \\
\hline Fleet $\mathrm{M}$ & 0.87 & 0.98 \\
\hline Success H & 0.80 & 0.98 \\
\hline Knowles H & 0.83 & 0.92 \\
\hline S9457 M & 0.86 & 0.95 \\
\hline S9043 M & 0.84 & 0.97 \\
\hline S9478 H & 0.86 & 0.98 \\
\hline S9452 M & 0.85 & 0.98 \\
\hline \multirow[t]{2}{*}{ Signal S } & 0.73 & 0.95 \\
\hline & $\underline{\text { Contrast }}$ & \\
\hline$M+H$ vs. $S$ & $* *$ & $* *$ \\
\hline M vs. $\mathrm{H}$ & $* *$ & * \\
\hline
\end{tabular}

*, ${ }^{* *}$ Contrast significant at the 0.05 or 0.01 level, respectively. $\ddagger \mathrm{H}=$ hybrid, $\mathrm{M}=$ meadow, and $\mathrm{S}=$ smooth bromegrass.

Table 8. Blade-to-total ratio [blade weight/(blade weight + sheath weight + internode weight)] for Phytomers 2, 3, and 4 in reproductive tillers of cultivars of hybrid, meadow, and smooth bromegrass at Brookings, SD in 2005 and 2009.

\begin{tabular}{cccccc}
\hline \multicolumn{5}{c}{ Population } \\
\hline Phytomer & Knowles & Success & Fleet & Paddock & Signal \\
\hline 2 & $0.13 \mathrm{a}$ & $0.19 \mathrm{a}$ & $0.10 \mathrm{a}$ & $0.11 \mathrm{a}$ & $0.19 \mathrm{a}$ \\
\hline 3 & $0.19 \mathrm{~b}$ & $0.23 \mathrm{~b}$ & $0.14 \mathrm{~b}$ & $0.16 \mathrm{~b}$ & $0.25 \mathrm{~b}$ \\
4 & $0.22 \mathrm{~b}$ & $0.24 \mathrm{~b}$ & $0.17 \mathrm{c}$ & $0.21 \mathrm{c}$ & $0.24 \mathrm{~b}$ \\
\hline 2 & & & $\underline{2009}$ & & $0.22 \mathrm{a}$ \\
\hline 3 & $0.16 \mathrm{a}$ & $0.17 \mathrm{a}$ & $0.12 \mathrm{a}$ & $0.12 \mathrm{a}$ & $0.28 \mathrm{~b}$ \\
4 & $0.30 \mathrm{c}$ & $0.27 \mathrm{c}$ & $0.25 \mathrm{c}$ & $0.25 \mathrm{c}$ & $0.35 \mathrm{c}$ \\
\hline
\end{tabular}

Means within populations within years followed by different letters are significantly different at the 0.05 level. 
Table 9. Biomass partitioning (\%) for Phytomers 2, 3, and 4 in reproductive tillers of initial growth harvested at anthesis for cultivars of meadow, hybrid, and smooth bromegrass at Brookings, SD on 18 June 2009.

\begin{tabular}{ccccc}
\hline Population & Internode Weight & Sheath weight & Blade weight & Leaf-to-stem \\
\hline Knowles & $56.7 \mathrm{a}$ & $36.9 \mathrm{ab}$ & $27.4 \mathrm{~b}$ & $0.23 \mathrm{a}$ \\
Success & $74.9 \mathrm{~cd}$ & $54.5 \mathrm{~d}$ & $35.1 \mathrm{c}$ & $0.22 \mathrm{a}$ \\
Fleet & $73.5 \mathrm{bc}$ & $36.3 \mathrm{a}$ & $22.4 \mathrm{a}$ & $0.17 \mathrm{~b}$ \\
Paddock & $87.5 \mathrm{~d}$ & $42 \mathrm{bc}$ & $27.3 \mathrm{~b}$ & $0.17 \mathrm{~b}$ \\
Signal & $61.8 \mathrm{ab}$ & $46.4 \mathrm{c}$ & $41.8 \mathrm{~d}$ & $0.28 \mathrm{c}$ \\
\hline
\end{tabular}

Means within columns followed by different letters are significantly different at the 0.05 level.

Table 10. Comparative morphology of three types of bromegrasses at Brookings, SD in 2009, six years after establishment.

\begin{tabular}{cccc}
\hline Type & VBW+g & Leaves tiller $^{-1}$ & Tillers $^{-2} \mathbf{g}$ \\
\hline Hybrid & $22 \mathrm{a}$ & $3.7 \mathrm{~b}$ & $687 \mathrm{a}$ \\
Meadow & $38 \mathrm{c}$ & $3.1 \mathrm{a}$ & $1375 \mathrm{~b}$ \\
Smooth & $29 \mathrm{~b}$ & $4.5 \mathrm{c}$ & $683 \mathrm{a}$
\end{tabular}

$\dagger \mathrm{VBW}=$ percent of total biomass that was composed of vegetative tillers. 9 Means within columns followed by different letters are significantly different at the 0.05 level.

\section{Evaluation of Selection for Vigor in Multiple Environments}

Significant differences were found between all meadow and hybrid populations, with the exception of S-9555, and AC Knowles hybrid bromegrass for forage production during 2013 and 2014 (data not shown). Due to poor persistence $(<30 \%$ plant survival) in July 2014 , data collection on the three hybrid bromegrasses was discontinued starting in 2015. All of the meadow bromegrass entries had $>90 \%$ survival for the duration of the study.

Significant differences $(\mathrm{P}>0.01)$ were found among meadow bromegrass populations for forage production during 2013 through 2017. Over those five years, SD Select, selected in South Dakota, produced significantly more forage than the other populations, with the exception of S-9522, which was selected in Saskatchewan. Both SD Select and S-9522 produced about 18\% more annual forage than Fleet. SD Select also produced more forage than the two experimental populations, S-9553 and S-9554, selected in eastern Canada (Table 11).

Significant differences $(\mathrm{P}<0.01)$ were also found among years for forage production. Annual means ranged from $0.65 \mathrm{Mg} \mathrm{ha}^{-1}$ in 2014 to $4.78 \mathrm{Mg} \mathrm{ha}^{-1}$ in 2016. Forage production was significantly greater in 2016 than any of the other years. Mean annual forage production for 2015 through 2017 was more than four times greater than average annual production during 2013 through 2014 (Table 12). The population $\mathrm{x}$ year mean square was not significant $(\mathrm{P}=$ $0.84)$. 
Table 11. Mean annual dry matter forage production for 1 cultivar and 4 selected populations of meadow bromegrass harvested at seed maturity on marginal crop land during 2013 through 2017 at Brookings, SD.

\begin{tabular}{cc}
\hline Entry & Forage productiong \\
\hline & Mg DM ha ${ }^{-1}$ \\
SD Select & $3.30 \mathrm{a}$ \\
S-9522 & $3.10 \mathrm{ab}$ \\
S-9553 & $2.95 \mathrm{bc}$ \\
S9554 & $2.77 \mathrm{bc}$ \\
Fleet & $2.72 \mathrm{c}$ \\
\hline
\end{tabular}

Means followed by different letters are significantly different at the 0.05 level.

Table 12. Mean annual dry matter forage production for 1 cultivar and 4 selected populations of meadow bromegrass harvested at seed maturity on marginal crop land during 2013 through 2017 at Brookings, SD.

\begin{tabular}{cc}
\hline Year & Forage productiong \\
\hline & $\mathrm{Mg} \mathrm{DM} \mathrm{ha}^{-1}$ \\
2016 & $4.78 \mathrm{a}$ \\
2017 & $4.00 \mathrm{~b}$ \\
2015 & $3.64 \mathrm{~b}$ \\
2013 & $1.28 \mathrm{c}$ \\
2014 & $0.65 \mathrm{~d}$ \\
\hline
\end{tabular}

geans followed by different letters are significantly different at the 0.05 level.

\section{Discussion}

\section{Forage Production}

The primary forage production period for perennial cool-season grasses in the northern Great Plains is spring, with peak standing crop normally reached by the end of June. Precipitation totals and patterns of distribution that occurred during the present study varied among years. Precipitation was above the $30-y r$ average (hereafter referred to as average) for every month, other than April, during the growing season of 2005, the first production year. And, as a result, mean total seasonal forage yield exceeded $8 \mathrm{Mg} \mathrm{ha}^{-1}$. In comparison, April-July precipitation during 2006 was only $60 \%$ of average, and consequently total seasonal yield was less than $4 \mathrm{Mg} \mathrm{ha}^{-1}$. However, lower precipitation may not have been the only influencing factor, since Lawrence and Ashford [20] found that the yield of smooth bromegrass in the first crop year tended to be higher than that obtained in subsequent years.

Yield of initial growth harvested on 24 June 2007 was likely reduced due to previous intensive management (i.e., 5 harvests over 2 yrs) rather than moisture availability. However, the lack of regrowth after defoliation in June was undoubtedly related to the $45 \%$ of average precipitation that fell during June and July. 
As was found in this study, Van Esbroeck et al. [5], working in Alberta, Canada, found smooth bromegrass produced lower regrowth yields than meadow and hybrid bromegrass. Seven weeks of regrowth during August and September at $52^{\circ} \mathrm{N}$ lat. produced $2.3 \mathrm{Mg} \mathrm{ha}^{-1}$ for meadow and hybrid bromegrass compared with $1.7 \mathrm{Mg} \mathrm{ha}^{-1}$ for smooth bromegrass. Differences in precipitation during August resulted in $43 \%$ difference between consecutive years for regrowth yield. In the present study, differences between years for precipitation during the regrowth period presumably influenced production. For example, during the first production year (2005), a regrowth period of 38 days in June and July, during which the precipitation was $31 \%$ greater than average, resulted in $2 \mathrm{Mg} \mathrm{ha}^{-1}$ of forage production, averaged across the 13 populations.

Coulman [7] found that regrowth capability of AC Knowles was substantially greater than that for Carlton smooth bromegrass; however, in a single-harvest system Carlton produced 5\% more forage than AC Knowles. We evaluated Signal rather than Carlton in the present study, and the only harvest for which AC Knowles out-produced Signal was the second regrowth harvest during 2005. Similar to what was reported by Coulman [7], AC Knowles produced slightly less than or was not different from Paddock, except during 2007, when Paddock had $70 \%$ more production than AC Knowles from initial spring growth (Table 4). The poorer performance of the hybrid bromegrass cultivars has also been seen in other climates with higher precipitation than that found on the Canadian Great Plains area, where these cultivars were developed (B. Coulman, personal observation).

In this 6-yr study, two cultivars and five experimental populations of meadow bromegrass showed potential for forage production in the northern Great Plains, USA. In particular, compared with smooth and hybrid bromegrasses, meadow bromegrass had: 1) higher total and regrowth forage production during the second and third years of a 3-yr period of intensive management, which spanned two years of early growing-season drought, and 2) better resilience, as indicated by higher tiller density and forage production during the spring following a year of rest and application of mixed fertilizer.

\section{Morphology}

Van Esbroeck et al. [5] looked at leaf number-tiller ${ }^{-1}$ for regrowth of smooth, meadow and hybrid bromegrass over a 49-d regrowth period during August and September in Alberta. They found fewer leaves.tiller ${ }^{-1}$ (3.0 for meadow bromegrass and 4.3 for smooth bromegrass) than in the present study ( 4.5 for meadow bromegrass and $>6$ for smooth bromegrass). However, they observed, as did we, that vegetative tillers of hybrid bromegrass had more leaves than tillers of meadow bromegrass and generally fewer leaves than tillers of smooth bromegrass, most notably in the second regrowth. Backcrossing the hybrid to smooth bromegrass, as was done for 'Success' hybrid bromegrass [21], might be expected to increase leaves.tiller ${ }^{-1}$ for first regrowth. Leaf to total weight ratio in their study was similar to what we observed, ranging from 0.88 for hybrids to 0.94 for mea- 
dow bromegrass [5].

The initial growth of 6-yr-old stands of meadow bromegrass could be morphologically differentiated from those of hybrid and smooth bromegrasses namely by their higher tiller density and greater relative contribution of vegetative tillers to total biomass. Biligetu and Coulman [22] also found that meadow bromegrass had higher tiller densities and a higher percentage of vegetative tillers than smooth or hybrid bromegrass. Tiller density for meadow bromegrass at anthesis in the present study was comparable to that of Ferdinandez and Coulman [4] in 3-yr-old stands in Saskatchewan. However, tiller densities for hybrid and smooth bromegrass in this study were only about $60 \%$ of those in Saskatchewan.

The leaf-to-stem ratio for meadow bromegrass in this study was $55 \%$ of that found in Saskatchewan at the same developmental stage (i.e., anthesis) (4); whereas, similar leaf-to-stem ratios were found for hybrid bromegrass in South $\mathrm{Da}$ kota and Saskatchewan.

In Saskatchewan, leaf-to-stem ratios were similar for meadow, hybrid, and smooth bromegrass; whereas, in this study leaf-to-stem ratio of reproductive tillers was lower for meadow compared to hybrid and smooth bromegrass. However, internode development for the hybrid and smooth bromegrasses was slower than that of the meadow bromegrass due to phenological differences between the three types in 2009. When observations were made, intercalary meristems were still active in the upper two to three phytomers for the hybrid and smooth bromegrass; whereas, generally only the intercalary meristem of the internode of the apical phytomer was still active for meadow bromegrass.

This more advanced morphological development of meadow bromegrass, compared with the hybrid and smooth bromegrasses, was more evident in 2009 than in the previous years. This may have been related to the generally more vigorous initial growth of meadow bromegrass, compared with hybrid and smooth bromegrass, after rest and nutrient application in May 2008. Ferdinandez and Coulman [23] reported that Fleet meadow bromegrass reached anthesis 10 to 14 days before Signal smooth bromegrass and three hybrid bromegrass populations at Saskatoon, $\mathrm{SK}\left(52^{\circ} \mathrm{N}\right.$ lat.).

\section{Evaluation of Selection for Vigor in Multiple Environments}

Forage production of perennial bromegrasses in the northern Great Plains is strongly dependent on adequate amounts of late summer/autumn and spring precipitation. Moisture is needed in autumn to promote tillering and tiller development; whereas, spring moisture promotes tiller mass. The low forage yields in 2013 and 2014 were undoubtedly due to amounts and distribution patterns of precipitation and soil nutrient characteristics. After transplanting in June 2012, the July through October precipitation was $43 \%$ of average. The drought continued through spring 2013, as the April through May precipitation was 78\% of average. Precipitation during June and July of 2013 was $10 \%$ above average, but August through October precipitation was 69\% of average. In 2014, similar to 
2013, April through May precipitation was 65\% of average.

Although, June through July 2014 precipitation was 30\% above average, the dry autumn of 2013 and dry spring of 2014 reduced vigor so that mean forage yield at seed maturity in 2014 was only $35 \%$ of mean forage yield in 2013. Also, no fertilizer was applied during the initial two-year (2013 through 2014) evaluation period. Forage production of meadow bromegrass has been shown to increase by $>250 \%$ as a result of $160 \mathrm{~kg} \mathrm{~N} \mathrm{ha}^{-1}$ fertilization [24].

In contrast, precipitation during April through May of each of 2015 through 2017 was $98 \%$ of the 30 -year average $(129 \mathrm{~mm})$. April through August precipitation for the three years ranged from $104 \%$ in 2017 to $117 \%$ in 2016 . Without doubt, the combination of adequate precipitation and enhanced soil fertility through $\mathrm{N}$-fertilization during this three-year period provided improved environmental conditions that vastly increased forage production, relative to 2013 through 2014.

Early observations of meadow bromegrass in the Great Plains suggested it was not well adapted to eastern Nebraska [25]. Differences were found among eight plant introduction accessions, but individual spaced plant yields were lower than the lowest performing smooth bromegrass accessions and check cultivar, 'Lincoln'.

More recently, selection for vegetative vigor and seed production and quality within Fleet [26], Paddock [27], and 'Regar' [18] resulted in a new 21-clone synthetic cultivar, 'Cache' with superior seedling vigor and forage production, relative to the source populations (i.e., cultivars), in Utah [28]. Similarly, the cultivar 'Montana', a 96-plant composite out of Regar visually selected for rapid regrowth after intensive cutting, produced more forage (i.e., 105\%) than Paddock, Regar, and Fleet across several dryland sites in Montana [29].

Mass selection in the present study, based on vegetative vigor (i.e., plant height and frequency of reproductive culms) at seed maturity in eastern South Dakota identified 15 out of 280 (i.e., 5\%) 6-yr-old plants of meadow bromegrass superior for those two traits after intensive simulated hay production management over a 3-yr period of below average precipitation. That management system, under those particular environmental conditions, greatly reduced the vigor of smooth bromegrass and hybrid bromegrass plants, compared to meadow bromegrass plants. Consequently none of the surviving original 200 hybrid bromegrass plants or the surviving original 40 smooth bromegrass plants in the 2004 source nursery planting was considered for selection within their respective groups for development of other Cycle 1 populations, in addition to SD Select, which was selected solely within the seven meadow bromegrass populations in the 2004 source nursery.

Selection for vegetative vigor within widely-separated and environmentally diverse locations (i.e., eastern South Dakota for SD Select, Saskatchewan for S-9522, Quebec for S-9553, or Prince Edward Island for S-9554) out of Fleet, Paddock, and six experimental lines from the University of Saskatchewan 
breeding program produced populations of meadow bromegrass that were superior to two selected hybrid bromegrass synthetics and AC Knowles in 1- and 2-year-old stands in eastern South Dakota, primarily due to the decline in stand of the hybrids in the third production year (i.e., 2015).

Some of the most problematic crop land in the northern Great Plains is that which is poorly drained and/or salt-impacted. Development of new cultivars of adapted perennial grass forage crops is one of the best approaches to remediating those problem areas. Results from this study indicated that meadow bromegrass, based on persistence and forage production on weakly saline marginal crop land, had greater potential than hybrid bromegrass for this purpose. 'Regar' meadow bromegrass, which is adapted to the Intermountain West and Northern Great Plains in areas with $>35 \mathrm{~cm}$ of annual precipitation, is considered to be adapted to weakly saline to sodic soils, similar to those in the present study [30].

Recently, Robins and Jensen [31] reported low correlations and strong qualitative (i.e., crossover) interactions for means of 63 half-sib families of meadow bromegrass for biomass and digestibility in spaced and seeded plot nurseries across environments in Utah. Those results led them to conclude that breeding of meadow bromegrass would be most efficient in sward plot nurseries. Vogel et al. [11] discussed the difficulty of improving forage yield in smooth bromegrass and pointed out that over 50 years of breeding resulted in only about 5\% increase in forage yield.

In this present study, visual selection for vegetative vigor and seed production in transplanted single-row source nurseries in South Dakota and vegetative vigor, rapid regrowth, and freedom from disease in spaced plant source nurseries in Saskatchewan composed of seven meadow, five hybrid, and one smooth bromegrass populations resulted in improved populations that out-performed the check cultivar, Fleet, by $18 \%$ for forage yield on marginal crop land over a five-year period of widely fluctuating annual precipitation in eastern South Dakota. The two aforementioned selected experimental populations from eastern Canada (i.e., Prince Edward Island and Quebec) performed similarly to Fleet in the present study.

In the 2004 source nursery which was located about $8 \mathrm{~km}$ from the 2012 evaluation nursery in eastern South Dakota, five-year mean total forage yields, summed across years, of the individual populations of meadow bromegrass, which included two cultivars, (i.e., Fleet and Paddock) and five experimental populations, ranged from 17.7 to $20.9 \mathrm{Mg} \mathrm{ha}^{-1}$. This range strongly suggested genetic variation for forage production among those populations that served as the source nursery for the plant selection evaluation component (i.e., 2012 nursery) of this present research.

However, as previously reported [29] mean total dry matter production in the source nursery (i.e., 2004 nursery) of the present study was similar for Fleet (18.5 $\mathrm{Mg} \mathrm{ha}^{-1}$ ) and Paddock (19.3 $\mathrm{Mg} \mathrm{ha}^{-1}$ ), just a $4 \%$ difference. The average of the two cultivars was closer to the mean of the lowest yielding experimental popula- 
tion (17.7 $\mathrm{Mg} \mathrm{ha}^{-1}$ ) compared with the mean of the highest yielding experimental population (20.9 $\mathrm{Mg} \mathrm{ha}^{-1}$ ). However, both cultivars were selected for seed production rather than forage yield per se [26] [27]. Of the 15 plants used to develop SD Select only one was chosen from the two cultivars, that being Paddock.

Results of this study indicated that SD Select, S-9522, and the experimental source populations (i.e., the meadow bromegrass populations in the 2004 nursery in South Dakota that were evaluated 2005-2009) from which they were selected in South Dakota (SD Select) or Saskatchewan (S-9522), hold significant promise for development of new cultivars of meadow bromegrass with increased forage yield potential on marginal cropland in the northern Great Plains.

\section{Acknowledgements}

These forage production trials and selection of synthetic populations were in accordance with an objective of Northeast Regional Area Multistate Project 1010, an international collaborative forage breeding project aimed at developing new cultivars of perennial cool-season grasses for semiarid and sub-humid regions of Canada and the USA

(http://www.cals.cornell.edu/cals/pbg/programs/departmental/forage/ne1010.cfm).

This study was conducted as part of a research objective, Bruce Coulman, Principal Scientist, approved by the Northeast Regional Area Multistate Project NE 1010 "Breeding and Genetics of Forage Crops to Improve Productivity, Quality, and Industrial Uses” committee membership, Donald R. Viands, Cornell University, Administrative Advisor. The research in South Dakota was partially supported by USDA NIFA Multistate Research Funds through the South Dakota State University Agricultural Experiment Station.

\section{Conflicts of Interest}

The authors declare no conflicts of interest regarding the publication of this paper.

\section{References}

[1] Araujo, M.R.A. and Coulman, B.E. (2002) Genetic Variation, Heritability and Progeny Testing in Meadow Bromegrass. Plant Breeding, 121, 417-424. https://doi.org/10.1046/j.1439-0523.2002.739124.x

[2] Ferdinandez, Y.S.N. and Coulman, B.E. (2001) Nutritive Values of Smooth Bromegrass, Meadow Bromegrass and Meadow X Smooth Bromegrass Hybrids for Different Plant Parts and Growth Stages. Crop Science, 41, 473-478.

[3] McCartney, D.H., Bittman, S. and Nuttall, W.F. (2004) The Influence of Harvest Management and Fertilizer Application on Seasonal Yield, Crude Protein Concentration and $\mathrm{N}$ off Take of Grasses in Northeast Saskatchewan. Canadian Journal of Plant Science, 84, 205-212. https://doi.org/10.4141/P02-118

[4] Ferdinandez, Y.S.N. and Coulman, B.E. (2000) Characterization of Meadow X Smooth Bromegrass Hybrid Populations Using Morphological Characteristic. Canadian Journal of Plant Science, 80, 551-557. https://doi.org/10.4141/P99-122 
[5] Van Esbroeck, G.A., Baron, V.S. and King, J.R. (1995) Regrowth of Bromegrass Species, a Bromegrass Interspecific Hybrid and Meadow Foxtail in a Short-Season Environment. Agronomy Journal, 87, 244-251.

[6] Ferdinandez, Y.S.N. and Coulman, B.E. (2002) Evaluating Genetic Variation and Relationships among Two Bromegrass Species and Their Hybrid Using RAPD and AFLP Markers. Euphytica, 125, 281-291. https://doi.org/10.1023/A:1015857614809

[7] Coulman, B.E. (2004) Knowles Hybrid Bromegrass. Canadian Journal of Plant Science, 84, 815-817. https://doi.org/10.4141/P03-167

[8] Colville, W.L., Chesnin, L. and McGill, D.P. (1962) Effect of Precipitation and Long-Term Nitrogen Fertilization on Nitrogen Uptake, Crude Protein Content and Yield of Bromegrass Forage. Agronomy Journal, 55, 215-218.

[9] Karn, J.F., Berdahl, J.D. and Frank, A.B. (2006) Nutritive Quality of Four Perennial Grasses as Affected by Species, Cultivar, Maturity and Plant Tissue. Agronomy Journal, 98, 1400-1409.

[10] Lauriault, L.M., Kirksey, R.E. and Vanleeuwen, D.M. (2005) Performance of Perennial Cool-Season Forage Grasses in Diverse Soil Moisture Environments, Southern High Plains, USA. Crop Science, 45, 909-915.

[11] Vogel, K.P., Moore, K.J. and Moser, L.E. (1996) Bromegrasses. In: Moser, L.E., et al., Eds., Cool-Season Forage Grasses. Agronomy Monograph, ASA, Madison, WI, 535-567.

[12] Harrison, T. and Romo, J.T. (1994) Regrowth of Smooth Bromegrass (Bromus inermis Leyss.) Following Defoliation. Canadian Journal of Plant Science, 74, 531-537. https://doi.org/10.4141/cjps94-095

[13] Jensen, K.B., Robins, J.G., Waldron, B.L. and Peel, M.D. (2006) Genetic Variation in Dry Matter Production and Nutritional Characteristics of Meadow Bromegrass under Repeated Defoliation. Crop Science, 46, 1948-1954.

[14] Knowles, R.P., Baron, V.S. and McCartney, D.H. (1993) Meadow Bromegrass. Agriculture Canada Publication 1889/E. Agriculture Canada, Ottawa. https://doi.org/10.5962/bhl.title.59606

[15] Boe, A. and Lee, D.K. (2007) Genetic Variation for Biomass Production in Prairie Cordgrass and Switchgrass. Crop Science, 47, 929-934.

[16] Analytical Software (2000) Statistix 7 User's Manual. Analytical Software, Tallahassee, FL.

[17] Damon, R.A. and Harvey, W.R. (1987) Experimental Design, ANOVA and Regression. Harper \& Row Publishers, New York.

[18] Alderson, J. and Sharp, W.C. (1994) Grass Varieties in the United States. USDA-SCS Agriculture Handbook No. 170. USDA-SCS, Washington DC. https://doi.org/10.5962/bhl.title.97052

[19] Smith, D. (1973) Distribution of Dry Matter and Chemical Constituents among the Plant Parts of Six Temperate-Origin Forage Grasses at Early Anthesis. Research Division, College of Agricultural and Life Sciences, University of Wisconsin-Madison, Madison, WI.

[20] Lawrence, T. and Ashford, R. (1969) Effect of Stage and Height of Cutting on the Drymatter Yield and Persistence of Intermediate Wheatgrass, Bromegrass and Reed Canarygrass. Canadian Journal of Plant Science, 49, 321-332. https://doi.org/10.4141/cjps69-054

[21] Coulman, B.E. (2006) Success Hybrid Bromegrass. Canadian Journal of Plant Science, 86, 745-747. https://doi.org/10.4141/P05-200 
[22] Biligetu, B. and Coulman, B.E. (2010) Quantifying Regrowth Characteristics of Three Bromegrasses (Bromus) Species in Response to Defoliation at Different Developmental Stages. Grassland Science, 56, 168-176. https://doi.org/10.1111/j.1744-697X.2010.00190.x

[23] Ferdinandez, Y.S.N., Somers, D.J. and Coulman, B.E. (2001) Estimating the Genetic Relationship of Hybrid Bromegrass to Smooth Bromegrass and Meadow Bromegrass Using RAPD Markers. Plant Breeding, 120, 149-153. https://doi.org/10.1046/j.1439-0523.2001.00555.x

[24] McCaughey, W.P. and Simons, R.G. (1996) Harvest Management and N-Fertilization Effects on Yield and Regrowth of Smooth Bromegrass, Crested Wheatgrass and Meadow Bromegrass in the Eastern Prairies. Canadian Journal of Plant Science, 76, 773-782.

[25] Vogel, K.P. (1983) Evaluation of Bromegrass Introductions for Forage Yield and Quality. University of Nebraska Agricultural Experiment Station Research Bulletin 300.

[26] Knowles, R.P. (1990) Registration of 'Fleet' Meadow Bromegrass. Crop Science, 30, 741. https://doi.org/10.2135/cropsci1990.0011183X003000030055x

[27] Knowles, R.P. (1990) Registration of 'Paddock' Meadow Bromegrass. Crop Science, 30, 741. https://doi.org/10.2135/cropsci1990.0011183X003000030056x

[28] Jensen, K.B., Waldron, B.L., Larson, S.R. and Peel, M.D. (2004) Registration of 'Cache' Meadow Bromegrass. Crop Science, 44, 2263-2264.

[29] Cash, S.D., Ditterline, R.L., Wichman, D.M. and Majerus, M.E. (2002) Registration of 'Montana' Meadow Bromegrass. Crop Science, 42, 2211-2212.

[30] USDA-NRCS (2012) Release Brochure for 'Regar' Meadow Bromegrass (Bromus biebersteinii). USDA-Natural Resources Conservation Service, Aberdeen Plant Materials Center, Aberdeen, No. 83210.

[31] Robins, J.G. and Jensen, K.B. (2017) Genotype X Environment Interaction Effects of Propagation and Defoliation of Meadow Bromegrass. Crop Science, 57, 2007-2014. https://doi.org/10.2135/cropsci2017.02.0072

\section{Abbreviations}

$\mathrm{H}$, hybrid bromegrass, $\mathrm{M}$, meadow bromegrass, $\mathrm{S}$, smooth bromegrass. 